\section{Changlin Wang}

4 Dept. E-commerce, School of E-commerce \& Logistics Management, Henan Economic Research 5 Center, Henan University of Economics and Law, Zhengzhou City, P. R. China, Email: $6 \quad$ drwangchanglin@gmail.com

\section{Thompson Teo}

\section{Mobile services use and citizen satisfaction in government: Integrating social benefits and uses and gratification theory}

\footnotetext{
Dept. Analytics \& Operations, Business School, National University of Singapore, Singapore,
}

Email: bizteosh@nus.edu.sg

\section{Yogesh K. Dwivedi}

School of Management, Swansea University Bay Campus, Fabian Way, Swansea, SA1 8EN Email: y.k.dwivedi@swansea.ac.uk

Marijn Janssen (Corresponding author)

Faculty of Technology, Policy and Management, Delft University of Technology, The Netherlands Email: M.F.W.H.A.Janssen@tudelft.nl (1)

\section{Abstract}

Purpose - Citizen satisfaction with the government is a longstanding and continuous concern in public administration. However, past research did not investigate the effect on satisfaction with the government in the context of mobile government (m-government). The purpose of this paper is to evaluate how the social benefits of citizens using m-government affect their satisfaction with the government.

Design/methodology/approach - Grounded in the Uses and Gratification Theory (UGT), we suggest that the satisfaction in m-government should be constructed in terms of the satisfaction with mgovernment and the satisfaction with the government. Our research model of citizen satisfaction in the context of m-government is tested through partial least squares (PLS) (SmartPLS 2.0) based on data collected from a survey study in China.

Findings - The results indicate that the three important social benefits, e.g., convenience, transparency, 
and participation, are positively associated with process gratification, whereas only convenience is positively associated with content gratification. The results suggest that both process gratification and content gratification are positively associated with citizen satisfaction with the government. Furthermore, the research suggests that process and content gratification have a mediating role, whereas compatibility has a moderating role.

Practical implications - This research provides insights to practitioners on how to facilitate citizen satisfaction by increasing citizens' social benefits and improving process and content gratification.

Originality/value - This study contributes to the literature by offering a framework for analyzing the impact of citizens' use of m-government on their satisfaction with the government. The work also contributes to UGT by categorizing user gratifications into process gratifications, content gratifications, and citizen satisfaction with the government.

Keywords Citizen satisfaction, Mobile government, E-government, Uses and gratifications theory, Transparency, Participation, Compatibility

Paper type Research paper

\section{Introduction}

Citizen satisfaction with the government is a longstanding and core concern in public administration (Verdegem \& Verleye, 2009; James, 2007). Many government agencies and public sector leaders have been increasingly concerned about the decline of citizen satisfaction over the last several years (Alawneh, Al-Refai, \& Batiha, 2013). This decline often results in a loss of public trust and confidence in governments (Welch, Hinnant, \& Moon, 2005). The need for citizen satisfaction is placing increasing demands on public administration to become more user-centered. Consequently, the crisis of citizen 
satisfaction with governments faced by the public sector has become increasingly prevalent in both developed and developing countries (Waldron-Moore, 1999). On the other hand, in recent years, governments have increasingly invested in information communication technologies (ICT) (Kurfalı, Arifoğlu, Tokdemir, \& Paçin, 2017; Al-Hujran, Al-Debei, Chatfield, \& Migdadi, 2015; Al Mansoori, Sarabdeen, \& Tchantchane, 2018) to improve their service model by becoming more citizen-centric (Dwivedi, Rana, Janssen, Lal, Williams, \& Clement, 2017; Rana, Dwivedi, Williams, \& Weerakkody, 2016; Rana, Dwivedi, Lal, Williams, \& Clement, 2017; Shareef, Kumar, Kumar, \& Dwivedi, 2011). Extant research indicated that citizen satisfaction is an appropriate dependent variable to measure IT use success in the public sector (e.g., Chen, Vogel, \& Wang, 2016; Chan, Thong, Venkatesh, Brown, $\mathrm{Hu}, \& \mathrm{Tam}, 2010)$. The issue of how to engender citizen satisfaction with governments via the use of ICT, especially mobile technology (m-technology), remains a challenge facing governments today (Gutierrez, O’Leary, Rana, Dwivedi, \& Calle, 2019; Yang, Jiang, Yao, Chen, \& Wei, 2018; Chen, Vogel, \& Wang, 2016).

With the rise of m-technologies and the popularity of smartphones, the government departments at all levels have used m-technologies to provide more and more public services to stakeholders (e.g., employees, citizens, businesses, and other organizations) anytime and anywhere in recent years (Hu, Chen, Hu, Larson, \& Butierez, 2011; Shareef, Kumar, Dwivedi, \& Kumar, 2016a; Dwivedi, Sahu, Rana, \& Baabdullah, 2018; Shareef, Raman, Baabdullah et al., 2019). This phenomenon is named mobile government (m-government) that can be viewed as a subset of e-government where access to government services is provided to citizens using mobile devices, such as mobile phones (Shareef, Dwivedi, Laumer, \& Archer, 2016b; Shareef, Dwivedi, Kumar, \& Kumar, 2016c; Shareef, Dwivedi, Stamati, \& Williams, 2014; Shareef, Archer, \& Dwivedi, 2012). For example, as of June 2020, Baidu 
Company's m-government service search volume was 10.779 billion times, and m-government and people's livelihood services (government and people's livelihood smart applets) totaled 5.515 billion. All 31 provinces (autonomous regions and municipalities) in China have implemented m-government and adopted WeChat public and Weibo accounts (CNNIC, 2020).

We reviewed the extant research on mobile services use, and we found that previous studies have focused primarily on the factors that drive users to adopt m-government, as well as the key success factors for m-government (Wang, Teo, \& Liu, 2020). We also found that there were only a few empirical studies on citizen satisfaction in the m-government context. These existing studies focus on citizen satisfaction with m-government systems (e.g., Veeramootoo, Nunkoo, \& Dwivedi, 2018; Chen, Vogel, \& Wang, 2016; Rana, Dwivedi, Williams, \& Weerakkody, 2015; Wang, 2014), and not on satisfaction with the government. Although some studies have emphasized the important impact of m-government on government satisfaction (e.g., Chen, Vogel, \& Wang, 2016; Wang, Teo, \& Liu, 2020), they have failed to build a chain "from citizen satisfaction with m-government to citizen satisfaction with government", making it difficult to understand the forming process of citizen satisfaction with government. More specifically, previous research usually considered m-government satisfaction as a single-dimensional variable, they failed to distinguish the satisfaction in the use of m-government from the technical level (i.e., the satisfaction with the m-government system itself) and the satisfaction with the government represented behind the m-government system. Giving that the government provides public services to citizens through the m-government system as a media, rather than directly providing face-to-face services to citizens, and extant studies have shown that citizen satisfaction with the government is conducive to enhancing citizens' trust in the government (e.g., Grimsley \& Meehan, 2007; Welch, Hinnant, \& Moon, 2005), we infer that citizen satisfaction with m-government may affect 
their satisfaction with the government Against the backdrop of declining public trust, improving citizen satisfaction with the government is conducive to eliminating the barriers between citizens and the government, reducing transaction costs, and enhancing public trust (Bertot, Jaeger, \& Grimes, 2010), it is necessary to study the formation process of citizens' satisfaction with the government in the context of m-government.

Researching citizen satisfaction in the m-government context is of great significance for both theory and practice. From a theoretical view, understanding the formation process of citizens' satisfaction with the government is benefit to provide a theoretical basis for improving citizen satisfaction via citizen satisfaction with the new technology. M-government shows similar advantages over e-government, including avoiding corruption and low productivity of governmental agencies, increasing efficiency, and effectiveness (Trimi \& Sheng, 2008), and has the potential to improve citizen satisfaction with the government (Janssen, Rana, Slade, \& Dwivedi, 2018; Tolbert \& Mossberger, 2006). Given the proliferation of m-government, more empirical studies on this topic are necessary. The significance of new ICT as a salient driver of citizen satisfaction with the government is found in various areas, including the use of websites (e.g., Lee, Lee, \& Lee-Geiller, 2020; Hong, 2013; Chan et al., 2010), e-government (e.g., Morgeson III, VanAmburg, \& Mithas, 2010; Welch et al., 2004), and social media (e.g., Demircioglu \& Chen, 2019; Aladwani, \& Dwivedi, 2018; Demircioglu, 2018). How the application of mobile technologies can improve citizen satisfaction with governments is still unclear. From a practical point, conducting this research can provide specific strategies for the government to improve citizen satisfaction in the m-government context. Governments in both developed and developing countries are actively developing digital technologies, and m-government is becoming an innovative complement to e-government (Shareef, Dwivedi, Laumer, \& Archer, 2016b; Shareef, 
1

Dwivedi, Kumar, \& Kumar, 2016c; Shareef, Dwivedi, Stamati, \& Williams, 2014; Shareef, Archer, \& Dwivedi, 2012; Trimi \& Sheng, 2008). Service providers (e.g., public agencies) must ensure an adequate interface to citizens to improve citizen satisfaction with the government.

The habits, experiences, and values that e-government users have formed may affect their satisfaction with m-government, and in turn, affect their satisfaction with the government. This relationship is named compatibility. Compatibility refers to "the degree to which an innovation is perceived as being consistent with the existing values, needs, and past experiences of potential users" (Moore \& Benbasat, 1991, p.195). Compatibility with the norms and experiences, such as past habits, values, and experience, is found as an important factor affecting citizens' adoption of new technologies. Past studies often regarded compatibility as an antecedent of intention to use e-government (e.g., Carter \& Bélanger, 2005; Chan, Thong, Venkatesh, Brown, Hu, \& Tam, 2010) and m-government (Shahzad, Xiu, Khan, \& Wang, 2019; Hung, Chang, \& Kuo, 2013). Other studies indicated that compatibility moderated the relationship between ICT use and outcomes (e.g., Gro., 2018; Islam, 2016). However, empirical evidence regarding the moderating role of compatibility in the formation process of citizen satisfaction remains scarce. Given that m-government utilizes new technology, we use compatibility as a moderator in our study to examine its role in citizen satisfaction.

In summary, there is a dearth of research on the impact of users' social benefits on citizen satisfaction in the context of m-government use. Hence, the objective of this study is to examine the relationship between m-government benefits and satisfaction within the government. The present study has utilized uses and gratifications theory (UGT) to construct a theoretical model of citizen satisfaction with the government in the m-government context to examine the factors affecting citizen satisfaction with the government. The model hypothesizes that citizens use m-government services provided by the 
public sector and experience the benefits of convenience, transparency, and participation, which are positively associated with citizens' gratifications (in terms of process gratification and content gratification) with m-government. In turn, gratifications are positively associated with citizen satisfaction with governments. Compatibility moderates the relationship between citizen gratifications and citizen satisfaction.

This study contributes to the extant literature in three aspects. First, we offer a framework and theorize the mediating mechanisms that link the benefits of m-government to citizen satisfaction with governments. Second, we contribute to the UGT by categorizing gratifications into three categories, namely, process gratifications, content gratifications, and citizen satisfaction with the government, and analyzing the relationships among these three categories. Third, we propose three important aspects of social benefits of m-government use, namely, convenience, transparency, and participation. Finally, we find compatibility positively moderates the relationship between process gratification (but not content gratification) and citizen satisfaction with the government.

The remaining sections of this paper are organized as follows. The next section (Section 2) introduces UGT, briefly reviews prior studies on m-government service and affordance, and develops our research model. The following section (Section 3) addresses the instrument development and data collection procedures (including the context of the study, pilot test, and sample. Partial least squares (PLS) (SmartPLS 2.0) using the two-step approach recommended by Anderson and Gerbing (1988) was used to test the research hypotheses. The empirical results are presented in Section 4. A discussion of results, research implications, limitations, and future research direction are presented in Section 5. Finally, Section 6 presents the key conclusions emerging from this research. 


\section{Theory development}

This section provides an overview of the literature on the UGT, social benefits of using m-government services, and proposes the research model and hypotheses.

\subsection{Uses and gratifications theory (UGT)}

UGT is an audience-centric approach that focuses on people's behavior in communication media, rather than the media's behavior towards people (Sutanto, Palme, Tan, \& Phang, 2013). UGT can be used as a theoretical framework to understand why people prefer to select particular types of media from a user-level perspective (e.g., traditional media-newspapers, telephones, and TV, and computer/mobile-mediated communication media — Internet) and what gratifications they obtain from their involvement (Ruggiero, 2000). Previous UGT studies have indicated that users employ a medium for three main categories of gratifications: content gratification, process gratification, and social gratification (Stafford, Stafford, \& Schkade, 2004). According to different media used, gratifications have different meanings. For example, in the context of the Internet, content gratification refers to being satisfied with content acquired from the Internet, process gratification refers to users gaining satisfaction from the experience of functional process (e.g., playing with Internet) (Han, Min, \& Lee, 2015), whereas social gratification refers to users gaining satisfaction from social ties.

UGT is suitable framework for our research for four reasons. First, we take the citizen perspective, which is consistent with UGT's audience-centered approach. Second, recently, scholars have tended to use UGT to explain and predict user behavior in the social media environment (e.g., Li, Yang, Chen, \& Yao, 2018; Sutanto, Palme, Tan, \& Phang, 2013). Considering m-government as providing new communication tools, and our research objective is to examine the impacts of m-government use on citizen satisfaction with the government, we can use UGT to explain and predict citizens' m- 
1

government usage behavior. Third, the basic logic of UGT is that individuals choose specific media based on their psychological and social motivations (Leung \&Wei, 2000). In our study, convenience, transparency, and participation are regarded as the social benefits of using m-government services (see section 2.2). Moreover, existing empirical studies have shown that content, process and social gratification drive user behavior (e.g., Sutanto, Palme, Tan, \& Phang, 2013; Leung \&Wei, 2000). Finally, previous research usually considered m-government satisfaction as a single-dimensional variable. To better understand citizen satisfaction with the government in the m-government context, we distinguish two levels of satisfaction in the use of m-government. The first is the technical level referring to the satisfaction with the m-government system itself. This level refers to the process and content gratification. The second level is the satisfaction with the government represented by the mgovernment. This level represents social gratification. Social gratification with the Internet includes four dimensions: chatting, friends, interactions and people (Stafford, Stafford, \& Schkade, 2004). Based on this definition, social satisfaction in our study refers to the satisfaction formed during the process of citizens using m-government to communicate and interact with government staff. This represents whether they are satisfied with the government. Hence, it is logical to use citizen satisfaction with the government to replace social gratification.

The operational definitions and resulting measures of three gratifications are based on extant studies (e.g., Stafford et al. 2004; Yang et al., 2018), but modified for m-government. Social gratification is replaced by citizen satisfaction with the government for the following three reasons. First, social gratification involves a wide range of forming and deepening social ties between users and other stakeholders. Specific to the m-government context, social ties mainly refer to the relationship between users and governments. Second, our approach is consistent with prior research on citizen 
satisfaction with the government in extant e-government (e.g., Welch, Hinnant, \& Moon, 2005) and mgovernment studies (e.g., Chen, Vogel, \& Wang, 2016). Third, citizen satisfaction with the government can appropriately reflect the government's social goal of developing m-government, which can be used to measure the m-government success for public institutions. Hence, the gratifications of uses of mgovernment contain content gratification, process gratification, and citizen satisfaction with the government. Content gratification refers to being satisfied with information and services provided by m-government, whereas process gratification refers to being satisfied with the use experience of $\mathrm{m}$ government. Finally, citizen satisfaction with the government refers to being gratified with the government. Prior work using UGT has mainly regarded process, content, and social gratifications as antecedents of media use (e.g., Li, Yang, Chen, \& Yao, 2018; Li, Guo, \& Bai, 2017), and paid little attention to the antecedents of these gratifications. Consequently, we analyze the benefits of the application of m-government from a social perspective.

\subsection{Social benefits of m-government services}

In recent years, adopting m-government in the public sector is becoming one of the major trends. For example, in China, government departments vigorously promote mobile phone mobile clients, WeChat public numbers, and QR codes in approval service applications. They also actively promote the wide coverage and high availability of government services on mobile phones to encourage. The government is increasingly investing in m-government to improve relationships with citizens. M-government has several advantages, such as mobility, localizability, personalization, and security (Wang, Teo, and Liu, 2020). Most prior research focused on their advantages from the technology perspective and the resulting satisfaction with the m-government system (e.g., Ahmad, \& Khalid, 2017; Chen, Vogel, \& Wang, 2016). Little attention has been paid to social benefits, such as convenience, transparency, and 
participation, and how these benefits affect citizens' satisfaction with the government. Social benefits are often key in policy-making and improving the relationships between the government and citizens. Although these social benefits also exist in PC-based e-government, m-government can provide citizens with personalized services anytime and anywhere as access to mobile phones is more conducive than access using desktops. Based on the extant research on e-government and m-government services, we summarize three important aspects of social benefits of using m-government services, namely, convenience, transparency, and participation (see Table 1). We choose these three aspects of the social benefits of m-government for the following reasons. First, these three aspects are often mentioned in the prior literature when analyzing the non-monetary benefits of government system use (e.g., Chen, Vogel, \& Wang, 2016; Mergel, 2013). Second, in the past research literature, these three aspects are regarded as important dimensions of public value (e.g., Scott, DeLone, \& Golden, 2016). Finally, the public sector is more concerned about realizing social goals rather than economic goals. We will elaborate on these three aspects and form hypotheses in the next section.

Table1 Social benefits of using m-government

\begin{tabular}{l|l|l}
\hline Dimensions & \multicolumn{1}{|c|}{ Definition } & References \\
\hline Convenience & $\begin{array}{l}\text { The ability to receive m-government } \\
\text { services at any time and location }\end{array}$ & $\begin{array}{l}\text { Scott et al (2016); Stamati et al (2015); } \\
\text { Norris \& Reddick (2013); Picazo-Vela et al } \\
\text { (2012); Chan et al (2010) }\end{array}$ \\
\hline \multirow{2}{*}{ Transparency } & $\begin{array}{l}\text { Acting openly toward all } \\
\text { stakeholders on procedures and } \\
\text { decisions }\end{array}$ & $\begin{array}{l}\text { Chen et al (2016); Song \& Lee, (2016); } \\
\text { Stamati et al (2015); Gunawong (2015); } \\
\text { Mergel (2013); Bertot et al (2010) }\end{array}$ \\
\hline Participation & $\begin{array}{l}\text { Involved and exert influence by } \\
\text { taking part in public services }\end{array}$ & $\begin{array}{l}\text { Scott et al (2016); Stamati et al (2015); } \\
\text { Gunawong (2015); Mergel (2013) }\end{array}$ \\
\hline
\end{tabular}

\subsection{Research model and hypotheses}

Figure 1 shows that the research model is constructed based on UGT and includes the three social benefits of using m-government, e.g., convenience, transparency, and participation, the three categories of uses gratifications, e.g., content gratification, process gratification, and citizen satisfaction with the government. Compatibility is used as a moderator in our model. 


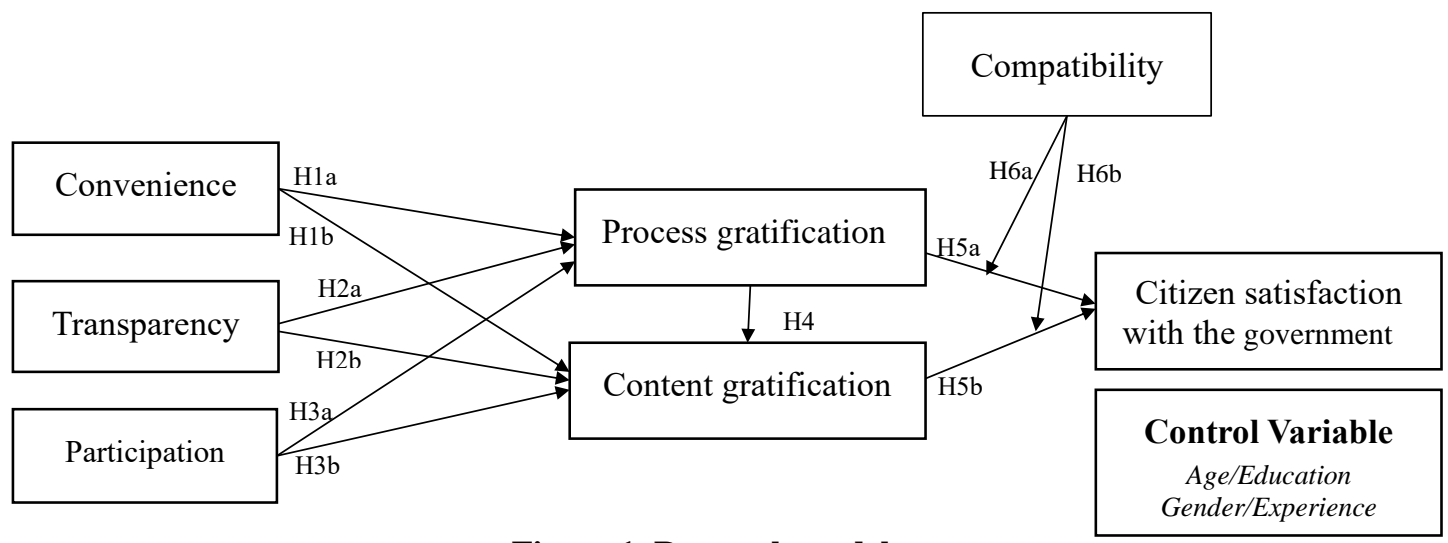

Figure 1. Research model

\subsubsection{Convenience}

Convenience refers to the ability to receive m-government services how and when the individual wants

(Scott, DeLone, \& Golden, 2016). In m-technology literature, convenience has often been termed as accessibility or ubiquity and is defined as the degree of access to services regardless of time and location (Kim \& Ammeter, 2014; Ashraf, Grunfeld, Hoque, \& Alam, 2017). These characteristics allow users to download and use real-time information and services wherever they are. Mobile-mediated communication services differ from other computer-mediated communication services in that they provide more convenience and instant connectivity at any time and any place (Clarke, 2001). Hence, convenience is considered a key attribute of mobile technology services and a key driver of use gratifications (Chen, Vogel, \& Wang, 2016). This ability to obtain information and services anytime and anywhere is convenient and enhances content gratifications (Sutanto, Palme, Tan, \& Phang, 2013).

Consequently, we hypothesize the following:

H1a: Convenience in accessing m-government services is positively associated with citizen process gratification.

H1b: Convenience in accessing m-government services is positively associated with citizen content gratification.

\subsubsection{Transparency}

Transparency refers to acting openly toward all stakeholders on procedures and decisions (Chen, Vogel, 
\& Wang, 2016). Many governments have worked to increase the transparency to improve citizen satisfaction with the government and build public trust (Song \& Lee, 2016). Prior research indicates that ICTs are regarded as a cost-effective and convenient means to increase transparency and to reduce corruption (Bertot, Jaeger, \& Grimes, 2010; Srivastava, Teo, \& Devaraj, 2016; Amrollahi \& Rowlands, 2017). There is evidence in previous literature suggesting the importance of transparency (Gunawong, 2015) as an antecedent to use gratifications in e-government (Jun, Wang, \& Wang, 2014).

M-government is more conducive to the disclosure of government information to better respond to public concerns. The public sector uses m-government to deliver real-time information and services to citizens, enhancing both the breadth and depth of information disclosure. Extant work suggests that governments providing information to citizens in a timely manner is the most important indicator of government transparency (Song \& Lee, 2016). M-government can provide citizens with mobile communication, mobile information searching, and mobile business services based on time-critical function originating from mobility (Yuan, Archer, Connelly \& Zheng, 2010), which is beneficial in improving the breadth and timeliness of information disclosure (Gunawong, 2015; Bannister \& Connolly, 2014). Given these advantages of m-government, transparency is expected to increase citizen's process gratifications. Due to location-sensitive function rooted in GPS technology, mgovernment can easily locate citizens and provide them with location-based services (Chen, Vogel, \& Wang, 2016), which enable the government to provide in-depth, personalized content and services to citizens. As such, transparency should increase user content gratification. Hence, it follows that:

H2a: Transparency in information is positively associated with citizen process gratification. $\mathrm{H} 2 \mathrm{~b}$ : Transparency in information is positively associated with citizen content gratification.

\subsubsection{Participation}

Participation refers to increasing opportunities to be involved in policy-making and to provide the 
government with the benefits of citizen collective expertise and information (Mergel, 2013). In recent years, governments increasingly use new ICTs to enhance citizen participation in decision-making (Scott, DeLone, \& Golden, 2016; Naranjo-Zolotov, Oliveira, \& Casteleyn, 2019), and to increase citizen satisfaction with the government and advance public trust (Lim, Tan, Cyr, Pan, \& Xiao, 2012).

M-government is a good tool to enable citizens to better engage and participate in decision-making through the introduction of social media (Trimi \& Sheng, 2008). Further, it can also assemble citizens and public managers in a creative and deliberative process by creating interactive and collaborative platforms (Hui \& Hayllar, 2010). M-government offers users the ability to receive information, communicate with the government, and participate in decision-making independent of the users' location and time (Trimi \& Sheng, 2008). In this way, increasing opportunities are created for citizens to take part in policy-making and share their collective knowledge, ideas, and expertise (Bertot, Jaeger, \& Grimes, 2012). In turn, this improves the quality of governmental decision and policy-making. These advantages are important in enhancing procedural justice (Chen, Vogel, \& Wang, 2016), and may increase process gratification. M-government can provide recommendations to citizens (e.g., providing policy information and enabling citizen feedback) based on their preferences or usage behavior. In this way citizens can better participate in government decision-making, thereby increasing citizen content gratification. Therefore, it follows that:

H3a: Participation is positively associated with citizen process gratification.

$\mathrm{H} 3 \mathrm{~b}$ : Participation is positively associated with citizen content gratification.

\subsubsection{Use gratifications and citizen satisfaction}

Uses gratification is broadly divided into two complementary dimensions: process gratification and content gratification (Sutanto, Palme, Tan, \& Phang, 2013). From a goal perspective, process gratification reflects the process goal related to the experience, whereas content gratification reflects 
the consumption goal that captures the functional benefits favored by citizens in consuming a product or service (Tan, Benbasat, \& Cenfetelli, 2013). In general, people prefer online services when the IT is functionally advanced enough for their needs and technically easy to use (Grönroos, Heinonen, Isoniemi, \& Lindholm, 2000; Wang, Du, Chiu, \& Li, 2018).

In the context of m-government, process gratification reflects how well m-government services are provided to citizens for achieving their process goals, and content gratification reflects how well mgovernment services are provided for attaining their consumption goals. Generally, the lack of good process experience will increase the perception of difficulty in obtaining high-quality content (Cenfetelli, Benbasat, \& Al-Natour, 2008; Bélanger \& Carter, 2008; Nourikhah \& Akbari, 2016). Conversely, the availability of superior service content will be rendered if it is made accessible to customers through efficient delivery. Therefore, citizen process gratification may be beneficial to enhance his/her content gratification. Hence, we hypothesize the following:

H4: Citizen process gratification is positively associated with citizen content gratification From a utilitarian perspective, citizen gratification with the process experience and content provided by m-government will increase the likelihood of individuals obtaining desirable outcomes (Chen, Vogel, \& Wang, 2016), and becoming satisfied with m-government services. The extant research indicates that the government has the potential to increase citizen satisfaction with the government through the appropriate utilization of ICTs (Bélanger \& Carter, 2008; Welch, Hinnant, \& Moon, 2005). Given that m-government has the advantage of mobility, localizability, and personalization, mgovernment provides process experience use and service content. Hence, better and more convenient services, which are better accessible and having complete information may reduce the information gap and improve citizen satisfaction with government. Therefore, it is hypothesized that: H5a: Citizen process gratification is positively associated with citizen satisfaction 
H5b: Citizen content gratification is positively associated with citizen satisfaction

\subsubsection{Compatibility}

The theory of task-technology fit suggests that if the requirement of tasks matches with available technologies, then users are likely to use technologies to perform the tasks (Goodhue \& Thompson, 1995). Hence, we argue that if citizens believe that m-government fits their lifestyles, values, and past usage experiences, then they are more likely to employ these services. Further, the level of work outcomes is determined by the degree of fit between the task and technology (Goodhue \& Thompson, 1995). This suggests that the more the technology fits the specific task characteristics, the higher the likelihood that the technology will improve task outcomes (Islam, 2016). In the m-government context, when the compatibility is high, the process and content of obtaining m-government services are highly consistent with citizens' past habits, values, and experiences. Higher comparability with current habits, values, and experiences, result in higher citizen satisfaction. Hence, we suggest that citizens' perception regarding compatibility will moderate the relationship between process and content gratifications with citizen satisfaction. Consequently, we propose the following hypotheses.

H6a: Compatibility positively moderates the relationship between citizen process gratification and citizen satisfaction

H6b: Compatibility positively moderates the relationship between citizen content gratification and citizen satisfaction

\section{Research method}

\subsection{Instrument development}

All measures in our model were adapted from validated instruments from extant studies (see Table 2).

Table 2. Measuremnts and references

\begin{tabular}{l|l|l}
\hline Constructs & \multicolumn{1}{|c|}{ Items } & References \\
\hline \multirow{5}{*}{ Convenience } & $\begin{array}{l}\text { CON1: It is important that I can use m-police around the clock. } \\
\text { CON2: It is important that I can access m-police from a number of } \\
\text { different locations (e.g., home, office). }\end{array}$ & $\begin{array}{l}\text { Scott, } \\
\text { DeLone, \& } \\
\text { Golden, } \\
\text { CON3: M-police allows me to be able to find desired information } \\
\text { quickly. }\end{array}$ \\
\hline
\end{tabular}




\begin{tabular}{|c|c|c|}
\hline Transparency & $\begin{array}{l}\text { Through m-police, the police station provides: } \\
\text { TRA1: Reliable information about its decision making. } \\
\text { TRA2: Reliable information about how its decisions affect me. } \\
\text { TRA3: Timely information about its actions. }\end{array}$ & $\begin{array}{l}\text { Chen, } \\
\text { Vogel, \& } \\
\text { Wang, } 2016\end{array}$ \\
\hline Participation & $\begin{array}{l}\text { PAR1: M-police allows me to have my say about things that matter } \\
\text { to me. } \\
\text { PAR2: M-police allows me to monitor the illegal activities of } \\
\quad \text { government employees. } \\
\text { PAR3: M-police makes me feel that decision-makers listen to me. } \\
\text { PAR4: M-police makes me feel that I am being consulted about } \\
\text { important issues. }\end{array}$ & $\begin{array}{l}\text { Scott, } \\
\text { DeLone, \& } \\
\text { Golden, } \\
2016\end{array}$ \\
\hline $\begin{array}{l}\text { Process } \\
\text { gratification }\end{array}$ & $\begin{array}{l}\text { PGR1: M-police use is interesting. } \\
\text { PGR2: M-police use is enjoyable. } \\
\text { PGR3: M-police use is pleasant. }\end{array}$ & $\begin{array}{l}\text { Li, Guo, \& } \\
\text { Bai, } 2017\end{array}$ \\
\hline $\begin{array}{l}\text { Content } \\
\text { gratification }\end{array}$ & $\begin{array}{l}\text { CGR1: The use of m-police is advantageous for my work. } \\
\text { CGR2: The use of m-police makes my work more efficient. } \\
\text { CGR3: The use of m-police improves the quality of the work I do. }\end{array}$ & $\begin{array}{l}\text { Li, Guo, \& } \\
\text { Bai, } 2017\end{array}$ \\
\hline Compatibility & $\begin{array}{l}\text { COM1: Using m-police is compatible with all aspects of my needs. } \\
\text { COM2: Using m-police fits well with my values. } \\
\text { COM3: Using m-police fits into my past experience. }\end{array}$ & $\begin{array}{l}\text { Chan et al. } \\
(2010)\end{array}$ \\
\hline $\begin{array}{l}\text { Citizen } \\
\text { Satisfaction } \\
\text { with the } \\
\text { government }\end{array}$ & $\begin{array}{l}\text { How do you feel about the police station overall by using m-police } \\
\text { services? } \\
\text { CSG1: Very dissatisfied/very satisfied. } \\
\text { CSG2: Very displeased/very pleased. } \\
\text { CSG3: Very frustrated/very contented. } \\
\text { CSG4: Absolutely terrible/absolutely delighted. }\end{array}$ & $\begin{array}{l}\text { Chen, } \\
\text { Vogel, \& } \\
\text { Wang, } 2016\end{array}$ \\
\hline
\end{tabular}

The wordings of all items were adapted to fit the m-government context when we translated the items

into Chinese using a back-translation method (Brislin, 1970). Transparency and citizen satisfaction with

the government were adapted from Chen, Vogel, and Wang (2016). Convenience and Participation were

measured using the items suggested by Scott, DeLone, and Golden (2016). Process gratification and

content gratification were adapted from Li, Guo, and Bai (2017), and compatibility was adapted from

Chan, Thong, Venkatesh, Brown, Hu, and Tam (2010). A seven-point Likert scales was used to measure

all variables, with the anchors being " $1=$ strongly disagree" and " $7=$ strongly agree". Prior studies have indicated that individual demographic differences have effects on usage behavior (Shao \& Kwon, 2019;

Teo, 2001). Therefore, respondents' education and experience were used as controls in the research

model. 


\subsection{Data collection procedures}

\subsubsection{Context of the study}

Communication between the police department and citizens (hereafter calls m-police) is mediated by an m-police app developed by Zhengzhou Public Security Bureau of Henan Province in 2018. M-police is regarded as a typical representative of m-government because the following three reasons. First, popular public services are provided by m-police, such as police news, vehicles-related business, citizenship-related business, case inquiry and online alarm related business, and online public security business consulting. These services are also available through offline services, as well as PC-based online services. However, citizens tend to use their mobile phones to access m-police or WeChat applets rather than go to the on-site counter or via the desktop computer. M-police can be used to make an appointment to apply for an ID card and a passport and deal with motor vehicle violations online. Further, m-policy can be used to check the progress of the business transactions by providing online business processing progress inquiries, publicizing the deadline for handling relevant transactions, and disclosing law enforcement actions. The m-police app provides online business processing progress inquiries, publicizes the deadline for handling relevant transactions, and discloses all law enforcement actions. Second, m-police also facilitates public participation in police affairs. The app has a reporting center where citizens can report violations of the police; there is also a column of citizen opinions, and citizens can advise on upcoming policies and suggestions for police work. Third, the most important point is that it can provide services related to Hukou (household registration). Hukou is a legal document that records the household population's basic information, including the person's name, date of birth, relatives, and marital status in China. Depending on their hukou, urban and rural citizens are assigned to different health insurance and education programs. A hukou is a key identification document for 
Chinese citizens and is an important administrative tool for the government to monitor its population.

The information system of China's administrative hukou belongs to the police station at all levels. In

China, citizens need to go to the police station registration hukou where the residence is located to register their newborn. Chinese citizens use ID cards in their daily lives, such as for services related to motor vehicles, e.g., driver's licenses, annual inspections, and traffic fines. All these services ae handled by the police station. Not surprisingly, the police station is one of the most contacted government departments for Chinese citizens.

\subsubsection{Pilot test}

The questionnaire was piloted among 40 citizens, who were not included in the main survey. In the pilot results, the Cronbach's $\alpha$ values of all variables were between 0.76-0.87 (Cronbach, 1970), and factors loadings for all observed variables were above 0.75 . This is considered as being acceptable by the thresholds recommended by Fornell \& Larcker (1981). Construct validity was evaluated using factor analysis, and all the items loaded onto their expected constructs (with loadings $>0.7$ ).

\subsubsection{Sample and data collection}

We sought the assistance of the m-police service provider to collect data. The m-police provider randomly invited 500 citizens across Henan province who come to the company to handle the business to fill out the questionnaire. One reason for selecting users from Henan province in central China is that it is typical of a microcosm of Chinese society in China (Wang, Teo, and Liu, 2020). We collected responses from 250 citizens within one month via a tax information provider. There were 207 valid questionnaires as 43 questionnaires had missing data. A T-test between valid and invalid responses results indicated no significant differences in terms of gender, age, education, and experience between different groups. Harman's (1976) one-factor test was used to assess the common method variance 


\begin{tabular}{l|l|l|l}
\hline \multicolumn{2}{c|}{ Characteristics } & Frequency & Percentage \\
\hline \multirow{3}{*}{ Gender (GEN) } & Male (0) & 121 & 58.5 \\
\cline { 2 - 4 } & Female (1) & 86 & 41.5 \\
\hline \multirow{4}{*}{ Age (years) } & $<20$ & 22 & 10.6 \\
\cline { 2 - 4 } & $20-29$ & 68 & 32.9 \\
\cline { 2 - 4 } & $30-39$ & 84 & 40.6 \\
\cline { 2 - 4 } & $\geq 40$ & & \\
\hline \multirow{3}{*}{ Education (EDU) } & & 33 & 15.9 \\
\hline \multirow{4}{*}{ M-government using experience (Yeas) } & $0.6-1$ & 90 & 43.5 \\
\cline { 2 - 4 } & $>1$ & 117 & 56.5 \\
\cline { 2 - 4 } & Below college & 42 & 20.3 \\
\cline { 2 - 4 } & College and above & 68 & 46.9 \\
\hline
\end{tabular}

(CMV). The results showed that no single factor accounted for the majority of variance, e.g., the most covariance explained by one factor is $27.9 \%$. We also followed the recommended procedural and statistical remedies as suggested by Podsakoff, MacKenzie, Lee, and Podsakoff (2003). The results suggested that there was no difference between the research model (the average factor loading is 0.932) and the marker variable model (the average factor loading is 0.27 ). This indicates that CMV was not a problem in our study. The demographics of our respondents are shown in Table 3.

Table 3. Demographics of samples $(N=207)$.

\section{Results}

We use Smart PLS 2.0 to test our measurement model and structural model because it is recognized as an effective method for measuring construct reliability and validity, and it employs a component-based approach with less restriction on sample size and residual distributions (Chin, Marcolin, \& Newsted, 2003).

\subsection{Measurement model}

For assessing the quality of the constructs, the reliability and validity of the measurement items were used to test the measurement model. Reliability (Cronbach's $\alpha$ ), composite reliability (CR), average variance 
Table 4. Correlations between constructs

\begin{tabular}{|c|c|c|c|c|c|c|c|c|c|c|c|c|c|}
\hline & Mean & SD & AVE & CR & Alpha & Item loadings & 1 & 2 & 3 & 4 & 5 & 6 & 7 \\
\hline 1.CON & 5.21 & 1.24 & 0.79 & 0.83 & 0.82 & $0.87 / 0.82 / 0.91$ & 0.89 & & & & & & \\
\hline 2.TRA & 4.98 & 1.08 & 0.82 & 0.79 & 0.76 & $0.86 / 0.83 / 0.78$ & 0.34 & 0.91 & & & & & \\
\hline 3.PAR & 4.24 & 1.39 & 0.78 & 0.82 & 0.88 & $0.82 / 0.88 / 0.82 / 0.85$ & 0.51 & 0.55 & 0.88 & & & & \\
\hline 4.PGR & 5.56 & 1.24 & 0.76 & 0.84 & 0.85 & $0.92 / 0.81 / 0.87$ & 0.72 & 0.42 & 0.53 & 0.87 & & & \\
\hline 5.CGR & 4.56 & 1.16 & 0.87 & 0.89 & 0.89 & $0.86 / 0.89 / 0.84$ & 0.56 & 0.43 & 0.47 & 0.56 & 0.93 & & \\
\hline 6.COM & 5.03 & 1.09 & 0.83 & 0.86 & 0.86 & $0.82 / 0 / 89 / 0.87$ & 0.32 & 0.39 & 0.38 & 0.35 & 0.37 & 0.91 & \\
\hline 7.CSG & 4.38 & 1.02 & 0.85 & 0.83 & 0.85 & $0.86 / 0.79 / 0.82 / 0.89$ & 0.49 & 0.42 & 0.46 & 0.47 & 0.47 & 0.53 & 0.92 \\
\hline
\end{tabular}

extracted (AVE), and factor analysis were used to evaluate convergent validity. For each of the constructs, the values of CR, AVE, and Cronbach's $\alpha$ exceeded the thresholds of 0.7, 0.5 and 0.7, respectively (Fornell \& Larcker, 1981). Table 4 shows the measurement model results, including information about reliability, validity, correlations, and factor loadings. In Table 4, all items have high factor loadings (ranging from 0.78-0.91) in their corresponding constructs, and Cronbach's alphas are between 0.76 and 0.89 in our model, which is well above the 0.70 criterion for internal consistency reliability. To test discriminant validity, We compared the square roots of AVEs with the correlations among the constructs. The average variance extracted (AVE) was greater than 0.50 (ranging from 0.76 to 0.87) in all cases and greater than the square of the correlations, and all AVEs' square roots (in bold) are greater than the correlations among constructs, suggesting discriminant validity (Chin, Marcolin, \& Newsted, 2003).

Note: (1) Alpha represents Cronbach's $\alpha$, (2) AVE $>0.50$; CR $>0.70$, and $\alpha>0.70$.

\subsection{Structural model}

Figure 2 shows the standardized path coefficients in our model. Our model accounted for $42 \%\left(R^{2}=0\right.$.

42) of the variance in citizen satisfaction. All hypotheses were supported with the exception of H2a and

$\mathrm{H} 3 \mathrm{~b}$. H1a and H1b were supported because the results indicated that convenience was positively associated with the process gratification $(b=0.36, p<0.001)$ and content gratification $(b=0.29, p<$ 

not affect path weights among the major constructs in the research model.

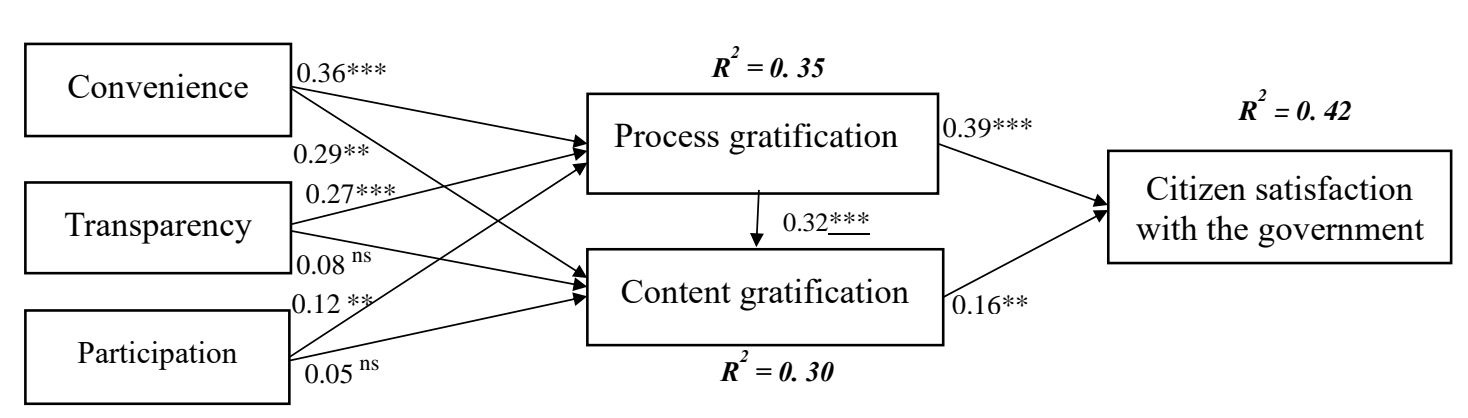

Figure 2. The results of research model

0.01), respectively. $\mathrm{H} 2 \mathrm{a}$ was supported as transparency was positively associated with process gratification $(b=0.27, p<0.001)$. Interestingly, transparency was not significantly positively associated with content gratification $(b=0.08, p>0.05)$; thus, $\mathrm{H} 2 \mathrm{~b}$ was not supported. H3a was supported because participation was positively associated with process gratification $(b=0.12, p<0.01)$. H3b was not supported since the results suggested that participation was not significantly positively associated with content gratification $(b=0.05, p>0.05)$. $\mathrm{H} 4$ was supported because process gratification was positively associated with content gratification $(b=0.32, p<0.001)$. H5a and H5b were supported because process gratification $(b=0.39, p<0.001)$ and content gratification $(b=0.16, p<0.01)$ were positively associated with citizen satisfaction with the government. Altogether, the model accounts for $39 \%$ of the variance in citizen satisfaction with the government. Moreover, the model with (without) control variables explained $41.9 \%(40.6 \%)$ variance of reactance, which indicated that all the control variables showed non-significant effects. We also examined the research model when all the control variables were precluded, and the results indicated no difference. This suggests that all the control variables do

\begin{abstract}
5
\end{abstract}
For further analysis, we examined the mediating effects of content gratification and process gratification. First, we tested the direct relationship between convenience, transparency, and participation with citizen satisfaction with the government. The results indicated that convenience $(b=$ 


\begin{tabular}{|c|c|c|c|c|c|}
\hline \multicolumn{2}{|c|}{ Paths coefficients } & \multirow{2}{*}{$\begin{array}{c}\begin{array}{c}\text { Full sample } \\
(\mathbf{N}=\mathbf{2 0 7})\end{array} \\
0.39 * * *\end{array}$} & \multirow{2}{*}{$\begin{array}{c}\begin{array}{c}\text { High } \\
\text { compatibility } \\
(\mathbf{N}=\mathbf{1 0 5})\end{array} \\
0.49 * * *\end{array}$} & \multirow{2}{*}{$\begin{array}{c}\begin{array}{c}\text { Low } \\
\text { compatibility } \\
(\mathbf{N}=\mathbf{9 2})\end{array} \\
0.21^{\mathrm{ns}}\end{array}$} & \multirow{2}{*}{$\begin{array}{c}\begin{array}{c}\text { t statistics } \\
\text { (high vs. low) }\end{array} \\
30.41^{* * *}\end{array}$} \\
\hline Process gratification $\rightarrow$ & $\begin{array}{l}\text { Citizen Satisfaction with } \\
\text { the government }\end{array}$ & & & & \\
\hline Content gratification $\rightarrow$ & $\begin{array}{l}\text { Citizen Satisfaction with } \\
\text { the government }\end{array}$ & $0.16^{* *}$ & $0.15 * * *$ & $0.18 * *$ & $12.34^{\mathrm{ns}}$ \\
\hline
\end{tabular}

$0.48, p<0.001)$, transparency $(b=0.39, p<0.001)$, and participation $(b=0.21, p<0.01)$ were positively associated with citizen satisfaction with the government. Second, as shown in Figure 2, we tested the structural model. Finally, the Sobel test was used to test the mediating effect (Sobel, 1982). The results indicated that process gratification partially mediated the relationships between convenience $(T=27.35, p<0.001)$, transparency $(T=22.59, p<0.01)$, and participation $(T=26.23, p<0.01)$ with citizen satisfaction with the government. The results also suggested that content gratification partially mediated the relationship between convenience $(T=32.62, p<0.01)$ and citizen satisfaction, but did not mediate the relationships between transparency $(T=28.17, p>0.05)$ and participation $(T=19.86, p>0.05)$ with citizen satisfaction with the government.

We also tested the moderating role of compatibility. We utilized a multiple-group approach, in which the groups were divided into high compatibility $(N 1=105)$ and low compatibility $(N 2=92)$ groups using the median (Baron \& Kenny, 1986). Further, we used the Sobel test to examine whether the moderating effect was significant (Sobel, 1986). The results (see Table 5) indicated that H6a $(t=$ $30.41, p<0.001)$ was supported, but H6b $(t=12.34, p>0.051)$ was not supported.

Table 5. Comparison of paths for the high and low compatibility group

Note: $* p<0.05 ; * * p<0.01, * * * p<0.001$.

We summarize the results of our hypotheses testing in Table 6.

Table 6. Summary of results on hypotheses testing

\begin{tabular}{|l|l|l|}
\hline H1a & $\begin{array}{l}\text { Convenience in accessing m-government services is positively associated with citizen process } \\
\text { gratification }\end{array}$ & Supported \\
\hline H1b & $\begin{array}{l}\text { Convenience in accessing m-government services is positively associated with citizen content } \\
\text { gratification }\end{array}$ & Supported \\
\hline
\end{tabular}




\begin{tabular}{|c|c|c|}
\hline $\mathrm{H} 2 \mathrm{a}$ & $\begin{array}{l}\text { Transparency in information provided by m-government services is positively associated with } \\
\text { citizen process gratification }\end{array}$ & $\begin{array}{l}\text { Not } \\
\text { supported }\end{array}$ \\
\hline $\mathrm{H} 2 \mathrm{~b}$ & $\begin{array}{l}\text { Transparency in information provided by m-government services is positively associated with } \\
\text { citizen content gratification }\end{array}$ & $\begin{array}{l}\text { Not } \\
\text { supported }\end{array}$ \\
\hline $\mathrm{H} 3 \mathrm{a}$ & Participation is positively associated with citizen process gratification & Supported \\
\hline $\mathrm{H} 3 \mathrm{~b}$ & Participation is positively associated with citizen content gratification & $\begin{array}{l}\text { Not } \\
\text { supported }\end{array}$ \\
\hline $\mathrm{H} 4$ & Citizen process gratification is positively associated with citizen content gratification & Supported \\
\hline H5a & Citizen process gratification is positively associated with citizen satisfaction & Supported \\
\hline $\mathrm{H} 5 \mathrm{~b}$ & Citizen content gratification is positively associated with citizen satisfaction & Supported \\
\hline H6a & $\begin{array}{l}\text { Compatibility positively moderates the relationship between citizen process gratification and } \\
\text { citizen satisfaction }\end{array}$ & Supported \\
\hline H6b & $\begin{array}{l}\text { Compatibility positively moderates the relationship between citizen content gratification and citizen } \\
\text { satisfaction }\end{array}$ & $\begin{array}{l}\text { Not } \\
\text { supported }\end{array}$ \\
\hline
\end{tabular}

\section{Discussion}

\subsection{Main findings}

Few studies had focused on the social benefits of using e-government. Most studies address the impact of these benefits on citizen trust (e.g., Song \& Lee, 2016; Kim \& Lee, 2012; Welch, Hinnant, \& Moon, 2005). Further, there is limited work in m-government despite its significance. We developed a research model encompassing social benefits of using m-government services and gratifications in mgovernment. Our field study of $207 \mathrm{~m}$-government users suggested that citizens used m-government services provided by the public sector resulting in the social benefits of convenience, transparency, and participation. These were associated with citizen process and content gratifications with m-government. In turn, process and content gratifications were positively associated with citizen satisfaction with the government. We also found that process gratification fully mediated the relationships between social benefits of using m-government with citizen satisfaction with the government. Content gratification fully mediated only the relationship between convenience and citizen satisfaction. Apart from the link from transparency $(\mathrm{H} 2 \mathrm{~b})$, participation $(\mathrm{H} 3 \mathrm{~b})$ to content gratification, and compatability moderating 
citizen content gratification and citizen satisfaction $(\mathrm{H} 6 \mathrm{~b})$, all the hypothesized relationships were supported.

We found that the effect of process gratification on government satisfaction is significantly greater than that of content gratification, which suggests that it is more necessary to improve the satisfaction of citizens' process gratification when the government uses m-government to improve the government satisfaction. Previous research on UGT is mainly used to explore the relationship between technical features and satisfaction of users with social media in the business sector (e.g., Ray, Dhir, Bala, \& Kaur, 2019; Han, Min, \& Lee, 2015). Few studies have used this as a theoretical framework to study the impact of service quality on citizens' continuance intention to use m-government. For example, the extant studies finds that the process and content gratification of the above studies had a positive effect on the dependent variable (e.g., continuance intention), and content gratification showed a greater effect on continuance intention than that of process gratification (e.g., Ding, Yang, Chen, Long, \& Wei, 2019; Li, Yang, Chen, \& Yao, 2018). In contrast, our research showed that process gratification had a greater effect on citizen satisfaction than content gratification. Future research could use different research scenarios (e.g., m-tax, m-traffic, and m-learning) to verify which kind of gratification has a greater impact on government satisfaction.

An unexpected result is that the relationship between transparency and content gratification was not found to be significant. Meanwhile, our result indicated that transparency is positively related to process gratification. This means that citizens are more concerned about the transparency of information, and the government can use the improvement of information transparency to increase their process gratification. Extant studies indicated that the relationship between transparency and satisfaction was inconsistent. For example, transparency was found to be positively related to citizen satisfaction (e.g., 
1 Yang, 2018), but transparency and satisfaction were also found to be negatively related (e.g., 2 Porumbescu, 2017). One possible reason for our result is that although the content catalogs provided by m-government in China are relatively complete (such as decision-making disclosure, management service disclosure, implementation and results disclosure, policy interpretation and response concerns), the specific content of the disclosure needs to be more detailed, timely and convenient. For example, although the Chinese government has made great progress in data disclosure, there are still many factors hindering the in-depth opening of government data, such as institutional barriers, data integrity and quality barriers, and user participation barriers (Huang, Lai, \& Zhou, 2017).

Another unexpected result is that the relationship between participation and content gratification was not supported, which is inconsistent with existing research (Alawneh, Al-Refai, \& Batiha, 2013; Kim \& Lee, 2012). One plausible reason is that citizens in China mainly use m-government to obtain information and complete transaction, rather than to participate (Xie, Qiao, Shao, \& Chen, 2017). Convenience, transparency, and participation are positively and significantly associated with citizen satisfaction with the government. These results show that we still need to pay attention to user participation in improving government satisfaction, because participation have significant effects on process gratification and government satisfaction, although the positive effect on content satisfaction is not significant. It may be necessary to further verify the validity of the results in different contexts in the future research, or improve the way citizens participate in m-government.

\subsection{Theoretical Contributions}

First, we contribute to m-government literature by offering a framework and theorizing the mediating mechanisms that link the social benefits of m-government use to citizen satisfaction. We extended UGT for the m-government context and use it to understand the factors affecting citizen satisfaction. Prior 
research on satisfaction in the e-government and m-government context has maintained a strict focus on citizen satisfaction with ICT (e.g., Chen, Vogel, \& Wang, 2016; Welch, Hinnant, \& Moon, 2005).

Our study utilized UGT to examine the factors affecting citizen satisfaction with the government in the context of m-government, which provides new insights to enhance citizen satisfaction with the government. We found that process gratification fully mediated the relationship between social benefits of using m-government and citizen satisfaction with the government, but content gratification only mediated the relationship between convenience and citizen satisfaction. This result is important for two reasons. One is that the ultimate goal of governments to develop m-government is to create public value and citizen satisfaction (Grimsley \& Meehan, 2007). Our result can provide guidance to evaluate mgovernment success. The other is that we have examined the factors affecting citizen satisfaction with the government, which provides insights into factors influencing citizen satisfaction.

Second, we contribute to UGT by categorizing user gratifications into three categories, namely, process gratification, content gratification, and citizen satisfaction with the government, and analyzed the relationships among them. Previous UGT studies have suggested that users employ content, process, and social gratification (Stafford, Stafford, \& Schkade, 2004), and that they are independent of each other. More importantly, although our research model is based on UGT, we substituted social gratification with citizen satisfaction to be consistent with prior research on citizen satisfaction in public administration research (e.g., Morgeson, 2012; Van Ryzin, 2005). We also added process gratification and content gratification into our model to better understand how to engender citizen satisfaction with the government. More importantly, we analyzed the relationships between them. Our results help decision-makers to take targeted measures to improve citizen satisfaction. For example, decision makers need pay more attention to advance citizens' process gratification (relative to content gratification) 
because our results indicates that process gratification shows greater effect on government satisfaction than that of content gratification.

Third, we propose three important social benefits of m-government, namely, convenience, transparency, and participation. Prior research on the benefits of e-commerce ( $\mathrm{Wu}$, Huang, Chen, Davison, \& Hua, 2018), e-government use, or m-government use, primarily focuses on technology's perspective. For example, Venkatesh, Chan, and Thong (2012) identified the key service attributes driving the use of e-government services, namely, usability, computer resource requirement, technical support provision, and security provision. Our study summarizes the three benefits of m-government use from the social perspective, which provides a new perspective for studying m-government value. This helps us better understand the government's social goals, because for the government, achieving social goals may be far more important than achieving economic goals (Grimsley \& Meehan, 2007).

Finally, we used compatibility as a moderator. Our results indicate that process is more important than content in m-government. Our study examined the role of compatibility in moderating the relationships between process and content gratifications, and citizen satisfaction. The results indicate that process gratification has a greater effect on citizen satisfaction for high compatibility groups. Beyond our expectation, the relationship between content gratification and citizen satisfaction was not moderated by compatibility. This confirms the literature that found that public services require a focus on the citizen use process and experience (Verdegem \& Verleye, 2009; Bertot, Jaeger, \& Grimes, 2010).

\subsection{Practical contributions}

Our results provide practitioners with rich insights on how to facilitate citizen satisfaction with the government via m-government. First, to enhance citizen satisfaction with the government, our research 
1

suggests that m-government vendor (governments) should improve citizens' gratifications with the process and content gratifications of m-government service, as our results indicated that citizens' content and process gratifications were positively related to citizen satisfaction with the government. For improving citizen satisfaction with the government from the perspective of process gratification, we suggest public management should increase the joy of m-government use. For example, reduce user anxiety by increasing the ease of use, facilitating people feeling confident about their ability to successfully acquire m-government services via training, and relieving privacy concerns by providing a safe use environment. For improving citizen satisfaction from the perspective of the content gratification, we suggest to improve the information and service quality. For example, on the one hand, governments should ensure information delivered to citizens is characterized by accuracy, completeness, consistency, timeliness, and uniqueness. On the other hand, governments should provide personalized information and services to meet users' real needs and the preferences of different citizens.

Second, to enhance gratifications with m-government services from the social perspective, we suggest governments to increase the social benefits of m-government usage. For example, to enhance process gratification with m-government, governments should improve the convenience, transparency, and participation features. Although the relationships between the two social benefits of m-governments uses (i.e., transparency and participation) were not supported, further analysis indicated that both of them were positively related to citizen satisfaction with the government. Hence, to enhance content gratification with m-government, governments should also improve the convenience, transparency, and participation. Specific measures to increase social benefits include increasing service channels (e.g., online, offline, integration) and self-service to facilitate citizens' access to information and services, increasing transparency by delivering information and increasing interaction, and increase public 
participation by creating interactive and collaborative m-government systems that facilitate user reviews, voices, and co-production.

Finally, we suggest m-government service providers should focus on improving citizen process gratification because our results indicate that the process gratification has a greater effect on citizen satisfaction than content gratification. Compatibility positively moderates the relationship between process gratification and citizen satisfaction. Hence, on the one hand, service providers should strengthen the service experience in the process of using m-government. On the other hand, they should pay attention to the compatibility with the citizen experience, values and habits when designing mgovernment.

\subsection{Limitations}

There are a few limitations and future research directions. First, the generalizability of our results may be limited due to the specific setting of our research. Data were collected from China based on a mpolice APP and the sample size is relatively small. Future studies could examine this model in other settings (e.g., m-tax, m-traffic, and m-health) and use a larger sample size. Second, our results were based on cross-sectional data, where causality cannot be inferred. Future research could use longitudinal data to test this model (Malaquias, Malaquias, \& Hwang, 2018). Third, convenience, transparency, and participation are regarded as important aspects of the social benefits of m-government use in our model. Future research could add trust (Verkijika, \& De Wet, 2018), accountability, and well-informedness into the social benefits to validate our model. Fourth, we have analysed the impact of process and content gratifications on citizen satisfaction with the government. Future research could examine the impact of citizen satisfaction with the government on process and content gratifications. Last but not least, future studies can also investigate whether there is a significant difference in citizen satisfaction 
1

with the government via different service channels, such as desktops and mobile phone use (Raphaeli, Goldstein, \& Fink, 2017).

\section{Conclusion}

Citizen satisfaction with governments is becoming one of the major concerns in public administration research and governments worldwide. Although prior research has addressed the potential of mgovernment for enhancing citizen satisfaction with the government, most researchers have focused on the technical dimensions of m-government (e.g., task-technology fit), while the social aspects have not attracted equal attention. Building on extant research, we developed a research model of citizen satisfaction with the government based on UGT. The results indicate that citizens use m-government services provided by the public sector resulting in convenience, transparency, and participation. These social benefits are, in turn, associated with process and content gratification. Both process and content gratification will then enhance citizen satisfaction with the government. We substituted social gratification by citizen satisfaction to be consistent with prior research on citizen satisfaction in public administration research. Process gratification fully mediates the relationships between social benefits of using m-government and citizen satisfaction with the government, but content gratification only mediates the relationship between convenience and citizen satisfaction. Moreover, we examine the role of compatibility, which positively moderates the relationship between process gratification (but not content) and citizen satisfaction. This study advances citizen satisfaction research by examining the factors affecting citizen satisfaction from the social perspective in m-government.

\section{Reference}

Ahmad, S. Z., \& Khalid, K. (2017), “The adoption of M-government services from the user's perspectives: Empirical evidence from the United Arab Emirates", International Journal of Information Management, Vol. 37 No. 5, 367-379.

Alawneh, A., Al-Refai, H. and Batiha, K. (2013), "Measuring user satisfaction from e-Government 
services: Lessons from Jordan”, Government Information Quarterly, Vol. 30 No. 3, pp. 277-288.

Aladwani, A. M., \& Dwivedi, Y. K. (2018), "Towards a theory of SocioCitizenry: Quality anticipation, trust configuration, and approved adaptation of governmental social media", International Journal of Information Management, Vol. 43, pp. 261-272.

Al-Hujran, O., Al-Debei, M. M., Chatfield, A. and Migdadi, M. (2015), "The imperative of influencing citizen attitude toward e-government adoption and use", Computers in Human Behavior, Vol.53 No. 1, pp.189-203.

Al Mansoori, K. A., Sarabdeen, J. and Tchantchane, A. L. (2018), "Investigating Emirati citizens' adoption of e-government services in Abu Dhabi using modified UTAUT model", Information Technology \& People, Vol. 31 No. 2, pp. 455-481.

Ahmad, S. Z. and Khalid, K. (2017), "The adoption of M-government services from the user's perspectives: Empirical evidence from the United Arab Emirates", International Journal of Information Management, Vol. 37 No. 5, pp. 367-379.

Amrollahi, A. and Rowlands, B. (2017), "Collaborative open strategic planning: a method and case study”, Information Technology \& People, Vol. 30 No. 4, pp. 832-852.

Ashraf, M., Grunfeld, H., Hoque, M. R. and Alam, K. (2017), “An extended conceptual framework to understand information and communication technology-enabled socio-economic development at community level in Bangladesh", Information Technology \& People, Vol. 30 No. 4, pp. 736-752.

Baron, R. M. and Kenny, D. A. (1986), "The moderator-mediator variable distinction in social psychological research: Conceptual, strategic, and statistical considerations", Journal of Personality and Social Psychology, Vol. 51 No. 6, pp. 1173-1182.

Bélanger, F. and Carter, L. (2008), "Trust and risk in e-government adoption", Journal of Strategic Information Systems, Vol. 17 No. 2, pp. 165-176.

Bertot, J. C., Jaeger, P. T. and Grimes, J. M. (2010), "Using ICTs to create a culture of transparency: E-government and social media as openness and anti-corruption tools for societies", Government Information Quarterly, Vol. 27 No. 3, pp. 264-271.

Brislin, R.W. (1970), "Back-translation for cross-culture research", Journal of Cross-Cultural Psychology, Vol. 1 No. 3, pp. 185-216.

Carter, L. and Bélanger, F. (2005). The utilization of e-government services: Citizen trust, innovation and acceptance factors. Information Systems Journal, Vol. 15 No. 1, pp. 5-25.

Cenfetelli, R. T., Benbasat, I. and Al-Natour, S. (2008), “Addressing the what and how of online services: Positioning supporting-services functionality and service quality for business-to-consumer success", Information Systems Research, Vol. 19 No. 2, pp. 161-181.

Chan, F. K., Thong, J. Y., Venkatesh, V., Brown, S. A., Hu, P. J. and Tam, K. Y. (2010), "Modeling citizen satisfaction with mandatory adoption of an e-government technology", Journal of the Association for Information Systems, Vol. 11 No. 10, pp. 519-549.

Chen, Z. J., Vogel, D., \& Wang, Z. H. (2016), "How to satisfy citizens? Using mobile government to 
reengineer fair government processes", Decision Support Systems, Vol. 82 No. 2, pp. 47-57.

Chin, W. W., Marcolin, B. L. and Newsted, P. R. (2003), "A partial least squares latent variable modeling approach for measuring interaction effects: Results from a Monte Carlo simulation study and an electronic-mail emotion/adoption study”, Information Systems Research, Vol. 14 No. 2, pp. 189-217.

Clarke III, I. (2001), "Emerging value propositions for m-commerce", Journal of Business Strategies, Vol. 25 No. 2, pp. 41-57.

CNNIC. (2020). 46th Statistical survey report on internet development in China. http://www.cnnic.net.cn/hlwfzyj/hlwxzbg/hlwtjbg/202009/P020200929546215182514.pdf (Oct 15, 2020)

Demircioglu, M. A. (2018), "Examining the effects of social media use on job satisfaction in the Australian public service: Testing self-determination theory, Public Performance \& Management Review, Vol. 41 No. 2, pp. 300-327.

Demircioglu M. A, and Chen C.A. (2019), "Public employees' use of social media: Its impact on need satisfaction and intrinsic work motivation", Government Information Quarterly, Vol. 36 No. 1, pp. 51-60.

Ding, Y., Yang, S., Chen, Y., Long, Q., \& Wei, J. (2019), “Explaining and predicting mobile government microblogging services participation behaviors: A SEM-neural network method". IEEE Access, Vol.7. No 3, pp. 39600-39611.

Dwivedi, Y. K., Sahu, G. P., Rana, N. P., \& Baabdullah, A. M. (2018), “Citizens” Awareness, Acceptance and Use of Mobile Government Services in India: An Exploratory Research", In Proceedings of the 11th International Conference on Theory and Practice of Electronic Governance (pp. 236-239).

Dwivedi, Y. K., Rana, N. P., Janssen, M., Lal, B., Williams, M. D., \& Clement, M. (2017), “An empirical validation of a unified model of electronic government adoption (UMEGA)", Government Information Quarterly, Vol. 34 No. 2, pp. 211-230.

Fornell, C. and Larcker, D. F. (1981), "Evaluating structural equation models with unobservable variables and measurement error", Journal of Marketing Research, Vol. 18 No. 1, pp. 39-50.

Goodhue, D. L. and Thompson, R. L. (1995), “Task-technology fit and individual performance”, MIS Quarterly, Vol. 19 No. 2, pp. 213-236.

Grimsley, M., \& Meehan, A. (2007). "E-government information systems: Evaluation-led design for public value and client trust", European Journal of Information Systems, Vol. 16 No. 2, pp. 134-148.

Groß, M. (2018), "Mobile shopping loyalty: The salient moderating role of normative and functional compatibility beliefs", Technology in Society, Vol. 55 No. 4, pp. 146-159.

Grönroos, C., Heinonen, F., Isoniemi, K. and Lindholm, M. (2000), "The NetOffer model: a case example from the virtual marketspace", Management Decision, Vol. 38 No. 4, pp. 243-252.

Gunawong, P. (2015), “Open government and social media: A focus on transparency”, Social Science 
Computer Review, Vol. 33 No. 5, pp. 587-598.

Gutierrez, A., O’Leary, S., Rana, N. P., Dwivedi, Y. K. and Calle, T. (2019), “Using privacy calculus theory to explore entrepreneurial directions in mobile location-based advertising: Identifying intrusiveness as the critical risk factor", Computers in Human Behavior, Vol. 95 No. 6, pp. 295-306.

Han, S., Min, J. and Lee, H. (2015), “Antecedents of social presence and gratification of social connection needs in SNS: a study of Twitter users and their mobile and non-mobile usage", International Journal of Information Management, Vol. 35 No. 4, pp. 459-471.

Harman, H. H. Modern factor analysis. Chicago: University of Chicago Press, 1976.

Hong, H. (2013), "Government websites and social media's influence on government-public relationships", Public Relations Review, Vol. 39 No. 4, pp. 346-356.

Hu, P. J. H., Chen, H., Hu, H. F., Larson, C. and Butierez, C. (2011), "Law enforcement officers' acceptance of advanced e-government technology: A survey study of COPLINK Mobile", Electronic Commerce Research and Applications, Vol. 10 No. 1, 6-16.

Hung, S. Y., Chang, C. M. and Kuo, S. R. (2013), "User acceptance of mobile e-government services: An empirical study”, Government Information Quarterly, Vol.30 No. 1, pp.33-44.

Huang, R., Lai, T. and Zhou, L. (2017), "Proposing a framework of barriers to opening government data in China: A critical literature review”, Library Hi Tech, Vol. 35 No. 3, pp. 421-438.

Hui, G. and Hayllar, M. R. (2010), "Creating public value in e - Government: A public - private citizen collaboration framework in Web 2.0", Australian Journal of Public Administration, Vol. 69 No. S1, 120-131.

Islam, A. N. (2016), "E-learning system use and its outcomes: Moderating role of perceived compatibility", Telematics and Informatics, Vol. 33 No. 1, pp. 48-55.

James, O. (2007), "Evaluating the expectations disconfirmation and expectations anchoring approaches to citizen satisfaction with local public services", Journal of Public Administration Research and Theory, Vol.19 No. 1, pp. 107-123.

Janssen, M., Rana, N. P., Slade, E. L. and Dwivedi, Y. K. (2018), "Trustworthiness of digital government services: Deriving a comprehensive theory through interpretive structural modelling", Public Management Review, Vol. 20 No. 5, pp. 647-671.

Jun, K. N., Wang, F. and Wang, D. (2014), "E-government use and perceived government transparency and service capacity: Evidence from a Chinese local government", Public Performance \& Management Review, Vol. 38 No. 1, pp. 125-151.

Karanasios, S. (2018). "Toward a unified view of technology and activity”, Information Technology \& People, Vol. 31 No. 1, pp. 134-155.

Kim, D. and Ammeter, T. (2014), "Predicting personal information system adoption using an integrated diffusion model", Information \& Management, Vol. 51 No. 4, pp.451-464. 
Kim, S., \& Lee, J. (2012), "E-participation, transparency, and trust in local government", Public Administration Review, Vol. 72 No. 6, pp. 819-828.

Kurfalı, M., Arifoğlu, A., Tokdemir, G. and Paçin, Y. (2017), “Adoption of e-government services in Turkey”, Computers in Human Behavior, Vol. 66 No. 1, pp. 168-178.

Lee, T., Lee, B. K., \& Lee-Geiller, S. (2020), "The effects of information literacy on trust in government websites: Evidence from an online experiment", International Journal of Information Management, Vol. 52, pp. 102098.

Leung, L., and Wei, R. 2000. "More Than Just Talk on the Move: Uses and Gratifications of the Cellular Phone", Journalism \& Mass Communication Quarterly, Vol 77 No 2, pp. 308-320.

Li, Y., Yang, S., Chen, Y. and Yao, J. (2018), "Effects of perceived online-offline integration and internet censorship on mobile government microblogging service continuance: A gratification perspective", Government Information Quarterly, Vol.35 No. 4, pp. 588-598.

Lim, E. T., Tan, C. W., Cyr, D., Pan, S. L. and Xiao, B. (2012), “Advancing public trust relationships in electronic government: The Singapore e-filing journey", Information Systems Research, Vol. 23 No. 4, pp. 1110-1130.

Malaquias, F., Malaquias, R. and Hwang, Y. (2018), "Understanding the determinants of mobile banking adoption: A longitudinal study in Brazil”, Electronic Commerce Research and Applications, Vol. 30 No. 4, pp. 1-7.

Mergel, I. (2013), "A framework for interpreting social media interactions in the public sector", Government Information Quarterly, Vol. 30 No. 4, pp. 327-334.

Moore, G. C. and Benbasat, I. (1991), Development of an instrument to measure the perceptions of adopting an information technology innovation. Information Systems Research, Vol. 2 No. 3, 192-222.

Morgeson, F. V. (2012), "Expectations, disconfirmation, and citizen satisfaction with the US federal government: Testing and expanding the model”, Journal of Public Administration Research and Theory, Vol.23 No. 2, pp. 289-305.

Morgeson III, F. V., VanAmburg, D. and Mithas, S. (2010), "Misplaced trust? Exploring the structure of the e-government-citizen trust relationship", Journal of Public Administration Research and Theory, Vol. 21 No. 2, pp. 257-283.

Naranjo-Zolotov, M., Oliveira, T. and Casteleyn, S. (2019), "Citizens' intention to use and recommend e-participation", Information Technology \& People, Vol. 32 No. 2, pp. 364-386.

Nourikhah, H. and Akbari, M. K. (2016), "Impact of service quality on user satisfaction: Modeling and estimating distribution of quality of experience using Bayesian data analysis", Electronic Commerce Research and Applications, Vol. 17 No. 3, pp. 112-122.

Norris, D. F. and Reddick, C. G. (2013), "Local e - government in the United States: Transformation 
or incremental change?", Public Administration Review, Vol. 73 No. 1, pp. 165-175.

Ishmatova, D. and Obi, T. (2009), "M-government services: user needs and value", The Journal of EGovernment Policy and Regulation, Vol. 32 No. 1, pp. 39-46.

Picazo-Vela, S., Gutiérrez-Martínez, I. and Luna-Reyes, L. F. (2012), "Understanding risks, benefits, and strategic alternatives of social media applications in the public sector", Government Information Quarterly, Vol. 29 No. 4, pp. 504-511.

Podsakoff, P. M., MacKenzie, S. B., Lee, J. Y. and Podsakoff, N. P. (2003), "Common method biases in behavioral research: A critical review of the literature and recommended remedies", Journal of Applied Psychology, Vol. 88 No. 5, pp. 879-903.

Porumbescu, G. A. (2017). Does Transparency improve citizens' perceptions of government performance? Evidence from Seoul, South Korea. Administration \& Society, Vol. 49 No. 3, pp. 443-468.

Rana, N. P., Dwivedi, Y. K., Lal, B., Williams, M. D., \& Clement, M. (2017), “Citizens' adoption of an electronic government system: towards a unified view", Information Systems Frontiers, Vol. 19 No. 3, pp. 549-568.

Rana, N. P., Dwivedi, Y. K., Williams, M. D., \& Weerakkody, V. (2016), “Adoption of online public grievance redressal system in India: Toward developing a unified view", Computers in Human Behavior, 59, 265-282.

Rana, N. P., Dwivedi, Y. K., Williams, M. D., \& Weerakkody, V. (2015), "Investigating success of an e-government initiative: Validation of an integrated IS success model", Information Systems Frontiers, Vol. 17 No. 1, pp. 127-142.

Raphaeli, O., Goldstein, A. and Fink, L. (2017), "Analyzing online consumer behavior in mobile and PC devices: A novel web usage mining approach”, Electronic Commerce Research and Applications, Vol. 26 No. 6, pp. 1-12.

Ray, A., Dhir, A., Bala, P. K., and Kaur, P. (2019), "Why do people use food delivery apps (FDA)? A uses and gratification theory perspective", Journal of Retailing and Consumer Services, Vol 51 No 6, pp.221-230.

Reddick, C. G., and Roy, J. (2013), "Business perceptions and satisfaction with e-government: Findings from a Canadian survey", Government Information Quarterly, Vol.30 No 1, pp.1-9.

Ruggiero, T. E. (2000), "Uses and gratifications theory in the 21st century", Mass Communication \& Society, Vol. 3 No. 1, pp. 3-37.

Scott, M., DeLone, W. and Golden, W. (2016), "Measuring eGovernment success: a public value approach”, European Journal of Information Systems, Vol. 25 No. 3, pp. 187-208.

Shareef, M. A., Raman, R., Baabdullah, A. M., Mahmud, R., Ahmed, J. U., Kabir, H., ... \& Mukerji, B. (2019), "Public service reformation: Relationship building by mobile technology", International Journal of Information Management, Vol. 49, pp. 217-227.

Shareef, M. A., Kumar, V., Dwivedi, Y. K. and Kumar, U. (2016a), "Service delivery through mobilegovernment (mGov): Driving factors and cultural impacts", Information Systems Frontiers, Vol. 18 
No. 2, pp. 315-332.

Shareef, M. A., Dwivedi, Y. K., Laumer, S., \& Archer, N. (2016b). Citizens' adoption behavior of mobile government (mGov): a cross-cultural study. Information Systems Management, Vol. 33, No. 3, pp. 268-283.

Shareef, M. A., Dwivedi, Y. K., Kumar, V., \& Kumar, U. (2016c), "Reformation of public service to meet citizens' needs as customers: Evaluating SMS as an alternative service delivery channel", Computers in Human Behavior, Vol. 61, pp. 255-270.

Shareef, M. A., Dwivedi, Y. K., Stamati, T., \& Williams, M. D. (2014), "SQ mGov: a comprehensive service-quality paradigm for mobile government", Information Systems Management, Vol. 31 No. 2, pp. 126-142.

Shareef, M. A., Archer, N., \& Dwivedi, Y. K. (2012), "Examining adoption behavior of mobile government", Journal of Computer Information Systems, Vol. 53, No. 2, pp. 39-49.

Shareef, M. A., Kumar, V., Kumar, U., \& Dwivedi, Y. K. (2011), "e-Government Adoption Model (GAM): Differing service maturity levels", Government Information Quarterly, Vol. 28, No. 1, pp. $17-35$.

Shao, C. and Kwon, K. H. (2019), "Clicks intended: An integrated model for nuanced social feedback system uses on Facebook", Telematics and Informatics, Vol. 39 No. 6, pp. 11-24.

Shahzad, F., Xiu, G., Khan, I. and Wang, J. (2019), "M-Government security response system: predicting citizens' adoption behavior", International Journal of Human-Computer Interaction, Vol. 35 No. 10, pp. 899-915.

Sobel, M. E. (1986), "Some new results on indirect effects and their standard errors in covariance structure models", Sociological methodology, Vol. 16 No. 1, pp. 159-186.

Song, C. and Lee, J. (2016), “Citizens' use of social media in government, perceived transparency, and trust in government", Public Performance \& Management Review, Vol. 39 No. 2, pp. 430-453.

Srivastava, S.C., Teo, T.S.H. and Devaraj, S. (2016), "You can't bribe a computer: Dealing with the societal challenge of corruption through ICT”, MIS Quarterly, Vol. 40, No. 2, pp. 511-526.

Stamati, T., Papadopoulos, T. and Anagnostopoulos, D. (2015), "Social media for openness and accountability in the public sector: Cases in the Greek context", Government Information Quarterly, Vol. 32 No. 1, pp. 12-29.

Stafford, T. F., Stafford, M. R. and Schkade, L. L. (2004), "Determining uses and gratifications for the Internet", Decision Sciences, Vol. 35 No. 2, pp. 259-288.

Sutanto, J., Palme, E., Tan, C. H. and Phang, C. W. (2013), “Addressing the personalization-privacy paradox: an empirical assessment from a field experiment on smartphone users", MIS Quarterly, Vol. 37 No. 4, pp. 1141-1164.

Tan, C. W., Benbasat, I. and Cenfetelli, R. T. (2013), "IT-Mediated Customer Service Content and Delivery in Electronic Governments: An Empirical Service Quality", MIS Quarterly, Vol. 37 No. 1, pp. 77-109. 
Teo, T. S. H. (2001), "Demographic and motivation variables associated with Internet usage activities", Internet Research, Vol. 11 No. 2, pp. 125-137.

Trimi, S. and Sheng, H. (2008), "Emerging trends in m-government", Communications ACM, Vol. 51 No. 5, pp. 53-58.

Tolbert, C. J. and Mossberger, K. (2006), "The effects of e - government on trust and confidence in government”, Public Administration Review, Vol. 66 No. 3, pp. 354-369.

Van Ryzin, G. G. (2005), "Testing the expectancy disconfirmation model of citizen satisfaction with local government”, Journal of Public Administration Research and Theory, Vol. 16 No. 4, pp. 599-611.

Venkatesh, V., Chan, F. K. and Thong, J. Y. (2012), "Designing e-government services: Key service attributes and citizens' preference structures”, Journal of Operations Management, Vol. 30 No. 1, pp. 116-133.

Verdegem, P. and Verleye, G. (2009), "User-centered E-Government in practice: A comprehensive model for measuring user satisfaction”, Government information quarterly, Vol. 26 No. 3, pp. 487-497.

Veeramootoo, N., Nunkoo, R., \& Dwivedi, Y. K. (2018), "What determines success of an e-government service? Validation of an integrative model of e-filing continuance usage", Government Information Quarterly, Vol. 35 No. 2, pp. 161-174.

Verkijika, S. F. and De Wet, L. (2018), "E-government adoption in sub-Saharan Africa”, Electronic Commerce Research and Applications, Vol. 30 No. 4, pp. 83-93.

Waldron-Moore, P. (1999), "Eastern Europe at the crossroads of democratic transition: Evaluating support for democratic institutions, satisfaction with democratic government, and consolidation of democratic regimes", Comparative Political Studies, Vol. 32 No. 1, pp. 32-62.

Wang, C. (2014), "Antecedents and consequences of perceived value in mobile government continuance use: An empirical research in China", Computers in Human Behavior, Vol. 34 No. 5, pp. 140-147.

Wang, J. N., Du, J., Chiu, Y. L. and Li, J. (2018), "Dynamic effects of customer experience levels on durable product satisfaction: Price and popularity moderation", Electronic Commerce Research and Applications, Vol. 28 No. 2, pp. 16-29.

Wang, C, and Teo, T, S. H. . (2020). "Online service quality and perceived value in mobile government success", International Journal of Information Management, Vol. 52 No. 6, pp. 1-12.

Wang, C. , Teo, T. S. H. , and Liu, L. . (2020). "Perceived value and continuance intention in mobile government service in china", Telematics and Informatics, Vol. 48 No.5, pp. 1-15 .

Welch, E. W., Hinnant, C. C. and Moon, M. J. (2005), "Linking citizen satisfaction with e-government and trust in government", Journal of Public Administration Research and Theory, Vol. 15 No. 3, pp. 371-391.

Wu, W., Huang, V., Chen, X., Davison, R. M. and Hua, Z. (2018), "Social value and online social shopping intention: the moderating role of experience", Information Technology \& People, Vol. 31 
$1 \quad$ No. 3, pp. 688-711.

2 Xie, Y., Qiao, R., Shao, G. and Chen, H. (2017), "Research on Chinese social media users' 3 communication behaviors during public emergency events", Telematics and Informatics, Vol. 34 No. $4 \quad 3$, pp. $740-754$.

$5 \quad$ Yang, Y. (2018), "Is transparency a double-edged sword in citizen satisfaction with public service? $6 \quad$ Evidence from China's public healthcare”, Journal of Service Theory and Practice, Vol. 28 No. 4, pp. $7 \quad 484-506$.

$8 \quad$ Yang, S., Jiang, H., Yao, J., Chen, Y. and Wei, J. (2018), "Perceived values on mobile GMS continuance: $9 \quad$ A perspective from perceived integration and interactivity", Computers in Human Behavior, Vol. 89 No. 12, pp. 16-26. 
Appendices

2 Appendix A Measuremnts and refereces.

\begin{tabular}{|c|c|c|}
\hline Constructs & Items & References \\
\hline Convenience & $\begin{array}{l}\text { CON1: It is important that I can use m-police around the clock. } \\
\text { CON2: It is important that I can access m-police from a number of } \\
\text { different locations (e.g., home, office). } \\
\text { CON3: M-police allows me to be able to find desired information } \\
\text { quickly. }\end{array}$ & $\begin{array}{l}\text { Scott, } \\
\text { DeLone, \& } \\
\text { Golden, } \\
2016\end{array}$ \\
\hline Transparency & $\begin{array}{l}\text { Through m-police, the police station provides: } \\
\text { TRA1: Reliable information about its decision making. } \\
\text { TRA2: Reliable information about how its decisions affect me. } \\
\text { TRA3: Timely information about its actions. }\end{array}$ & $\begin{array}{l}\text { Chen, } \\
\text { Vogel, \& } \\
\text { Wang, } 2016\end{array}$ \\
\hline Participation & $\begin{array}{l}\text { PAR1: M-police allows me to have my say about things that matter } \\
\text { to me. } \\
\text { PAR2: M-police allows me to monitor the illegal activities of } \\
\text { government employees. } \\
\text { PAR3: M-police makes me feel that decision-makers listen to me. } \\
\text { PAR4: M-police makes me feel that I am being consulted about } \\
\text { important issues. }\end{array}$ & $\begin{array}{l}\text { Scott, } \\
\text { DeLone, \& } \\
\text { Golden, } \\
2016\end{array}$ \\
\hline $\begin{array}{l}\text { Process } \\
\text { gratification }\end{array}$ & $\begin{array}{l}\text { PGR1: M-police use is interesting. } \\
\text { PGR2: M-police use is enjoyable. } \\
\text { PGR3: M-police use is pleasant. }\end{array}$ & $\begin{array}{l}\text { Li, Guo, \& } \\
\text { Bai, } 2017\end{array}$ \\
\hline $\begin{array}{l}\text { Content } \\
\text { gratification }\end{array}$ & $\begin{array}{l}\text { CGR1: The use of m-police is advantageous for my work. } \\
\text { CGR2: The use of m-police makes my work more efficient. } \\
\text { CGR3: The use of m-police improves the quality of the work I do. }\end{array}$ & $\begin{array}{l}\text { Li, Guo, \& } \\
\text { Bai, } 2017\end{array}$ \\
\hline Compatibility & $\begin{array}{l}\text { COM1: Using m-police is compatible with all aspects of my needs. } \\
\text { COM2: Using m-police fits well with my values. } \\
\text { COM3: Using m-police fits into my past experience. }\end{array}$ & $\begin{array}{l}\text { Chan et al. } \\
(2010)\end{array}$ \\
\hline $\begin{array}{l}\text { Citizen } \\
\text { Satisfaction } \\
\text { with the } \\
\text { government }\end{array}$ & $\begin{array}{l}\text { How do you feel about the police station overall by using m-police } \\
\text { services? } \\
\text { CSG1: Very dissatisfied/very satisfied. } \\
\text { CSG2: Very displeased/very pleased. } \\
\text { CSG3: Very frustrated/very contented. } \\
\text { CSG4: Absolutely terrible/absolutely delighted. }\end{array}$ & $\begin{array}{l}\text { Chen, } \\
\text { Vogel, \& } \\
\text { Wang, } 2016\end{array}$ \\
\hline
\end{tabular}


$1 \quad$ Appendix B. Item loadings and cross-loadings.

\begin{tabular}{|l|l|l|l|l|l|l|l|}
\hline Items & CON & TRA & PAR & COM & PGR & CGR & CSG \\
\hline CON1 & $\mathbf{0 . 8 7}$ & 0.34 & 0.46 & 0.65 & 0.53 & 0.32 & 0.49 \\
\hline CON2 & $\mathbf{0 . 8 2}$ & 0.31 & 0.49 & 0.68 & 0.49 & 0.34 & 0.44 \\
\hline CON3 & $\mathbf{0 . 9 1}$ & 0.33 & 0.45 & 0.63 & 0.56 & 0.29 & 0.42 \\
\hline TRA1 & 0.35 & $\mathbf{0 . 8 6}$ & 0.43 & 0.43 & 0.43 & 0.43 & 0.41 \\
\hline TRA2 & 0.30 & $\mathbf{0 . 8 3}$ & 0.35 & 0.40 & 0.40 & 0.41 & 0.39 \\
\hline TRA3 & 0.32 & $\mathbf{0 . 7 8}$ & 0.42 & 0.38 & 0.38 & 0.38 & 0.40 \\
\hline PAR1 & 0.45 & 0.44 & $\mathbf{0 . 8 2}$ & 0.48 & 0.40 & 0.30 & 0.42 \\
\hline PAR2 & 0.42 & 0.45 & $\mathbf{0 . 8 8}$ & 0.43 & 0.42 & 0.34 & 0.49 \\
\hline PAR3 & 0.48 & 0.47 & $\mathbf{0 . 8 2}$ & 0.47 & 0.45 & 0.35 & 0.48 \\
\hline PAR4 & 0.46 & 0.39 & $\mathbf{0 . 8 5}$ & 0.46 & 0.44 & 0.43 & 0.46 \\
\hline COM1 & 0.63 & 0.40 & 0.49 & $\mathbf{0 . 8 2}$ & 0.53 & 0.36 & 0.49 \\
\hline COM2 & 0.67 & 0.37 & 0.52 & $\mathbf{0 . 8 9}$ & 0.45 & 0.30 & 0.39 \\
\hline COM3 & 0.58 & 0.35 & 0.46 & $\mathbf{0 . 8 7}$ & 0.47 & 0.33 & 0.42 \\
\hline PGR1 & 0.58 & 0.43 & 0.42 & 0.48 & $\mathbf{0 . 9 2}$ & 0.33 & 0.46 \\
\hline PGR2 & 0.53 & 0.42 & 0.39 & 0.52 & $\mathbf{0 . 8 1}$ & 0.34 & 0.48 \\
\hline PGR3 & 0.55 & 0.38 & 0.43 & 0.43 & $\mathbf{0 . 8 7}$ & 0.37 & 0.40 \\
\hline CGR1 & 0.36 & 0.37 & 0.36 & 0.41 & 0.38 & $\mathbf{0 . 8 6}$ & 0.37 \\
\hline CGR2 & 0.29 & 0.41 & 0.34 & 0.38 & 0.36 & $\mathbf{0 . 8 4}$ & 0.32 \\
\hline CGR3 & 0.32 & 0.34 & 0.38 & 0.32 & 0.29 & $\mathbf{0 . 8 9}$ & 0.35 \\
\hline CSG1 & 0.47 & 0.41 & 0.42 & 0.46 & 0.43 & 0.45 & $\mathbf{0 . 8 6}$ \\
\hline CSG2 & 0.42 & 0.34 & 0.53 & 0.38 & 0.38 & 0.42 & $\mathbf{0 . 7 9}$ \\
\hline CSG3 & 0.39 & 0.39 & 0.47 & 0.42 & 0.44 & 0.48 & $\mathbf{0 . 8 2}$ \\
\hline CSG4 & 0.45 & 0.36 & 0.39 & 0.46 & 0.40 & 0.46 & $\mathbf{0 . 8 9}$ \\
\hline
\end{tabular}

THOMPSON S.H. TEO (bizteosh@nus.edu.sg) is a professor in the School of Business, National University of Singapore, Singapore. His research interests include knowledge management, sustainability, e-government, and technology adoption. Thompson has served as 
a senior associate editor for the European Journal of Information Systems, an editorial review board member for IEEE Transactions on Engineering Management, and regional editor (Asia and Pacific) for the International Journal of Information Management. He is currently serving as associate editor for Information \& Management, Communications of the AIS, and Omega, as well as an editorial board member for MIS Quarterly Executive. He has co-edited four books on information systems and is a four-time winner of the SIM Paper Competition. He won the Best Associate Editor Award 2017 from the Communications of the AIS.

YOGESH K. DWIVEDI (y.k.dwivedi@swansea.ac.uk) is a Professor of Digital Marketing and Innovation, Founding Director of the Emerging Markets Research Centre (EMaRC) and Co-Director of Research at the School of Management, Swansea University, Wales, UK. Professor Dwivedi is also currently leading the International Journal of Information Management as its Editor-in-Chief. His research interests are at the interface of Information Systems (IS) and Marketing, focusing on issues related to consumer adoption and diffusion of emerging digital innovations, digital government, and digital and social media marketing particularly in the context of emerging markets. Professor Dwivedi has published more than 300 articles in a range of leading academic journals and conferences that are widely cited (more than 21 thousand times as per Google Scholar). Professor Dwivedi is an Associate Editor of the Journal of Business Research, European Journal of Marketing, Government Information Quarterly and International Journal of Electronic Government Research, and Senior Editor of the Journal of Electronic Commerce Research. More information about Professor Dwivedi can be found at: http://www.swansea.ac.uk/staff/som/academic-staff/y.k.dwivedi/

MARIJN JANSSEN is a Full Professor in ICT \& Governance in the Technology, Policy and Management Faculty of Delft University of Technology. His research is focused on ICTarchitecting and design science in situations in which multiple public and private organizations need to collaborate, in which ICT plays an enabling role, there are various ways to proceed, and socio-technical solutions are constrained by organizational realities and political wishes. His research interests are in the field of design science, orchestration, shared services, smart cities, computational IA algorithms and open and big data and infrastructures. He has been involved in more than $8 \mathrm{EU}$ and NWO funded project. Marijn is a founding board member of Digicampus - a quadruple helix innovation partnership - in which government, business, science, and citizens work together to innovate public services. He is Co-Editor-in-Chief of Government Information Quarterly (CiteScore of 10.3 in 2019), chair of the IFIP WG8.5 in ICT and public administration, conference chair of IFIP EGOV-CeDEM-ePart series. He was ranked as one of the leading e-government researchers in surveys in 2009, 2014, and 2016. He was nominated in 2018 and 2019 by Apolitical as one of the 100 most influential people in the Digital Government worldwide https://apolitical.co/lists/digital-government-world100. He has published over 500 refereed publications, his google h-score is 62 , having over $16 \mathrm{~K}$ citations. More information: www.tbm.tudelft.nl/marijnj. 